\title{
$\mathrm{TiN}$ 및 $\mathrm{ZrN}$ 코팅된 교정용 브라켓의 부식특성
}

\author{
김원기, 김도영, 최한철" \\ 조선대학교 치과대학 생체재료학교실 및 생체재료나노계면활성화센터, 2단계 BK21
}

\section{Corrosion Characteristics of TiN and ZrN Coated Orthodontic Brackets}

\author{
W.G. Kim, D.Y. Kim, H.C. Choe" \\ Department of Dental Materials \& Research Center of Nano-Interface Activation for Biomaterials, \\ College of Dentistry, 2nd Stage of Brain Korea 21 for College of Dentistry, \\ Gwangju 501-759, Korea
}

(Received August 11, 2008 ; revised August 26, 2008 ; accepted August 28, 2008)

\begin{abstract}
The dental orthodontic bracket requires good mechanical properties, such as elastic strength and frictional resistance, combined with a high resistance to corrosion. The objective of this study was to investigate the effects of TiN and $\mathrm{ZrN}$ coating on corrosion resistance of orthodontic brackets using various electrochemical methods. Brackets manufactured by Ormco Co. were used, respectively, for experiment. Ion plating was carried out for coatings of bracket using $\mathrm{Ti}$ and $\mathrm{Zr}$ coating materials with nitrogen gas. Ion plated surface of each specimen was observed with field emission scanning electron microscopy (FE-SEM), energy dispersive Xray spectroscopy (EDS) and electrochemical tester. The corrosion potential of the TiN and $\mathrm{ZrN}$ coated bracket was comparatively high. The current density of $\mathrm{TiN}$ and $\mathrm{ZrN}$ coated bracket was smaller than that of noncoated bracket in $0.9 \% \mathrm{NaCl}$ solution. Pit nucleated at angle of bracket slot.
\end{abstract}

Keywords : Orthodontic bracket, TiN coating, ZrN coating, Surface treatment

\section{1. 서 론}

일반적으로 금속이나 교정재료에 내식성과 내마 모성을 부여하기 위하여 금속공학적으로 $\mathrm{TiN}$ 과 $\mathrm{ZrN}$ 을 보호피막으로 코팅하는 연국가 계속되고 있으 며 $\mathrm{TiN}$ 은 면심입방격자 $(\mathrm{fcc})$ 구조와 $4.235 \AA$ 의 격자 상수를 가지며 $2000 \mathrm{Hv}$ 이상의 경도를 나타내고 $\mathrm{ZrN}$ 은 $2500 \mathrm{Hv}$ 의 경도를 나타낸다고 보고 ${ }^{1}$ 하고 있다. 대체적으로 $\mathrm{TiN}$ 보다는 $\mathrm{ZrN}$ 피막이 안정하 고 표면의 특성이 좋음을 알 수 있으며 우수한 화 학적 안정성으로 내식성이나 내마모성을 필요로 하는 재료에 코팅2)하고 있다. 현재 응용되고 있는 코팅방법은 $\mathrm{TiCl}_{4}, \mathrm{~N}_{2}$ 및 $\mathrm{H}_{2}$ 가스를 이용하는 $\mathrm{CVD}$ (chemical vapor deposition), ion-plating법을 포함하 는 PVD(physical vapor deposition)법이 사용되고 있

*Corresponding author. E-mail : hcchoe@chosun.ac.kr
달. 과거에는 $\mathrm{ZrN}$ 과 $\mathrm{TiN}$ 코팅이 주로 $\mathrm{CVD}$ 법에 의해 수행되었으나 반응가스에 의한 오염과 $600^{\circ} \mathrm{C}$ 이상의 고온처리에 따른 모재의 변형)을 피하기 위 해 현재는 주로 PVD법에 의해 처리되고 있으며 그 중 ion-plating은 다른 PVD 방법에 비하여 코팅막 과 기지와의 접착력이 가장 우수한 장점이 있다. 일 반적으로 $\mathrm{ZrN}$ 과 $\mathrm{TiN}$ 박막의 기계적 성질은 코팅층 의 표면이나 계면특성에 의해 크게 영향을 받으므 로 이러한 결함을 억제하는 것이 중요하다. Harju 등 ${ }^{5)}$ 은 강에 질화층을 형성시킨 후 $\mathrm{TiN}$ 을 코팅하여 이 질화층이 $\mathrm{TiN}$ 코팅층의 내마모성에 미치는 영 향을 조사한 결과 질화층을 형성시키지 않은 경우 보다 우수한 내마모성을 갖는다고 하였으나 현재까 지의 연구자들에 따르면 코팅층의 높은 경도와 인 성 및 모재-박막층간의 우수한 접착력을 얻기 위해 서는 모재의 온도가 중요하며 ion-plating 방법이 좋 은 방법이라고 알려져 있다. 또한 재료의 내식성을 
향상시키기 위해 모재에 $\mathrm{TiN}$ 코팅을 행하며 전해 액에서 산화피막 $\left(\mathrm{TiO}_{2}\right)$ 의 형성을 촉진하여 생체적 합성과 재료의 안정성을 증가시키고 $\mathrm{TiN}$ 박막이 결 함부위를 막아 내식성을 향상시키는 것으로 보고되 어 있다). 그러나 교정재료에 ion-plating 법을 이용 하여 $\mathrm{TiN}$ 을 코팅하였을 때의 마찰력이나 교정력에 미치는 연구는 있으나 $\mathrm{ZrN}$ 을 코팅하여 내식성과 내 마모성 및 생체안정성을 고찰한 연구는 거의 없는 실정이다.

따라서 본 연구에서는 내마모 및 내식성이 우수 하고 광택으로 심미성을 겸비한 $\mathrm{TiN}$ 과 $\mathrm{ZrN}$ 을 교정 용 브라켓에 ion-plating시킨 후, 브라켓의 표면특성 을 조사하였다.

\section{2. 실험 방법}

\section{1 연구재료}

본 실험의 코팅과 부식시험에 사용된 브라켓은 Ormco사(Glendora, USA)의 mini diamond를 사용하 였다.

\section{2 연구방법}

2.2.1 브라켓의 $\mathrm{TiN}$ 및 $\mathrm{ZrN}$ ion-plating

Ion plating은 고체물질을 가열 혹은 입자를 충돌 시켜 원자, 분자로 분해하고 다시 이것을 D.C나 R.F 전원으로 이온화시켜 처리 물질의 표면에 응축시켜 서 박막을 형성하는 방법이다.

시험편을 장착한 후에 진공챔버를 $3.0 \times 10^{-5}$ torr 까지 배기시키고 mass flow controller를 이용하여 $\mathrm{Ar}$ gas를 10 20 mtorr로 공급하였다. 이후 $900 \mathrm{~W}$ 의 power로 $\mathrm{Ar}$ 플라즈마를 발생시킨 후 시료대에 $\mathrm{DC}$ 를 인가하여 약 10 분 동안 산화층을 비롯한 시 험편 표면의 오염물질을 제거한 후, 진공챔버를 다 시 $3.0 \times 10^{-5}$ torr로 배기시켰다. Ion-plating을 위하 여 질소가스를 $\mathrm{TiN}$ 코팅의 경우 $10 \sim 20 \mathrm{mtorr}, \mathrm{ZrN}$ 코팅의 경우는 9 10 mtorr로 공급하였으며 코팅시 간을 $10 \mathrm{~min}$ 으로 하여 코팅층의 두께가 $2.0 \sim 2.5 \mu \mathrm{m}$ 가 되도록 하였다. 시편의 회전 속도는 $0.5 \mathrm{RPM}$ 으 로 하여 브라켓의 모든 부위에 코팅이 균일하게 이 루어지도록 하였으며 접착도를 증가시키기 위하여 온도는 $350 ~ 380^{\circ} \mathrm{C}$ 로 하였다.

\subsection{2 코팅된 브라켓의 표면관찰 및 조성분석}

Ion plating된 브라켓 표면은 금속현미경과 FESEM(field emission scanning electron microscopy) 으로 관찰하였으며 조성은 분산 X-선 분광기(energy dispersive X-ray spectroscopy, EDS)를 사용하여 분
석하였다.

\subsection{3 전기화학적 부식시험}

전기화학적 방법을 이용한 부식시험은 potentiostat (model:263A, EG \& G Co, USA)을 사용하여 동전 위법으로 실시하였다. 전해액 $700 \mathrm{ml}$ 를 넣고 각각 의 시편을 정전위 장치에 연결한 후 포화칼로멜전 극(saturated calomel electrode, $\mathrm{SCE}$ )을 표준전극으 로 하였으며 작업전극은 준비된 시편으로 하였다. 시편과 표준전극(reference electrode)간의 거리를 약 $1 \mathrm{~mm}$ 로 조절하였으며, 보조전극(counter electrode) 으로 고밀도 탄소전극을 사용하였다. 양극분극곡선 (anodic polarization curve)을 얻기 위해 $36.5 \pm 1{ }^{\circ} \mathrm{C}$ 의 $0.9 \% \mathrm{NaCl}$ 전해액 $(\mathrm{pH}$ 가 5.34$)$ 에서 동전위방법 을 이용하여 $100 \mathrm{mV} / \mathrm{min}$ 의 주사속도로 $-500 \mathrm{mV}$ 에 서 $+1300 \mathrm{mV}$ 까지 전위를 걸어 1 차 전기화학적 부 식시험을 하였으며 실험시마다 시편과 전해액을 교 환하였다. $\mathrm{X}$ 축은 전류밀도의 로그값을 $\mathrm{Y}$ 축은 전위 로 하여 곡선을 얻었다.

\subsection{4 부식표면 관찰}

$0.9 \% \mathrm{NaCl}$ 전해액에서 코팅된 시편의 전기화학 적 거동을 조사하기 위하여 동전위 시험을 행한 후 브라켓 표면의 금속조직변화를 조사하기 위하여 금 속현미경(metallurgical microscope, Olympus, Tokyo, Japan), FE-SEM 및 EDS를 사용하여 관찰하였다.

\section{3. 결과 및 고찰}

\subsection{TiN 및 $\mathrm{ZrN}$ 코팅된 교정용 브라켓의 표면조사}

스테인리스강 브라켓에 ion-plating된 $\mathrm{ZrN}$ 과 $\mathrm{TiN}$ 표면을 주사전자현미경으로 관찰한 결과를 Fig. 1 3 에 나타내었다. Fig. 1은 브라켓에 코팅을 하지 않 은 경우의 FE-SEM 사진으로 (a)는 저배율로 코팅 된 브라켓의 전체 표면상태를 나타내며 (b)는 사진 (a)의 $\mathrm{A}$ 지점에서 1000 배로 확대한 것이다. $\mathrm{A}$ 는 교 정선과 직접 접촉이 이루어지는 부위로 기계적 가 공에 의한 스크래치와 기계적 결함이 그대로 존재 하였다. Fig. 2와 3에서 100,000배의 고배율로 본 표면은 아주 작은 알갱이로 구성되었는데 $\mathrm{TiN}$ 과 $\mathrm{ZrN}$ 을 코팅시킨 후 코팅층의 단면부를 전자현미경 으로 조사한 결과 주상정의 조직(columnar structure) 을 보이고 특정방향으로의 결정이 성장하면서 코 팅이 잘 이루어진 것으로 보고되어 있다 ${ }^{7}$. 이는 표 면에너지가 가장 낮은 방향으로 결정성장이 이루 어지며 TiN(111)이 우선방위로 성장하며 $\mathrm{TiN}(200)$ 과 $\mathrm{TiN}(220)$ 의 방향으로도 성장한다. 이러한 성장 

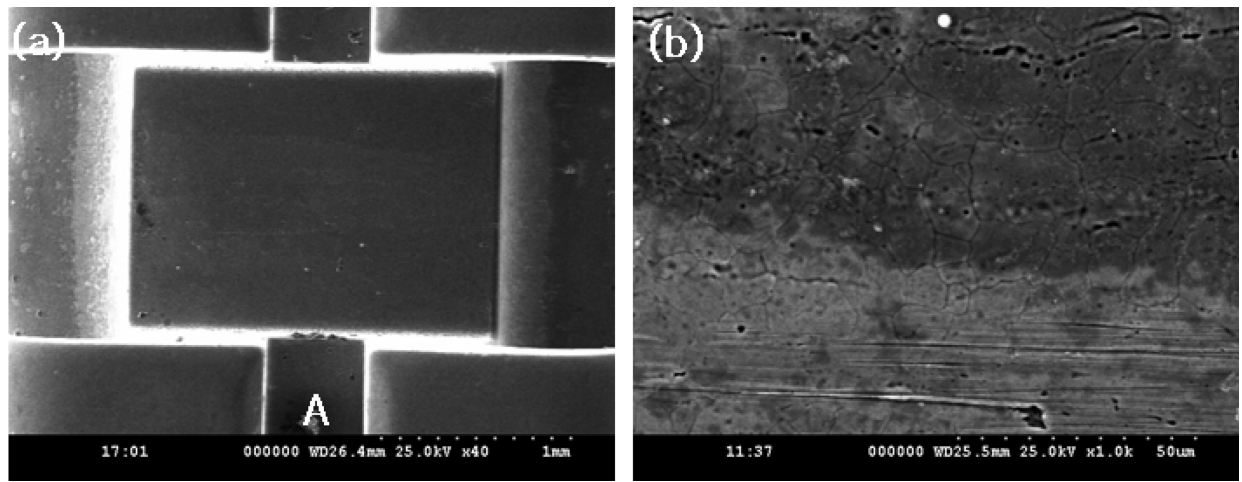

Fig. 1. The surface morphology of dental bracket observed by FE-SEM. (a) non-coated bracket (b) slot surface at A point of photo (a).
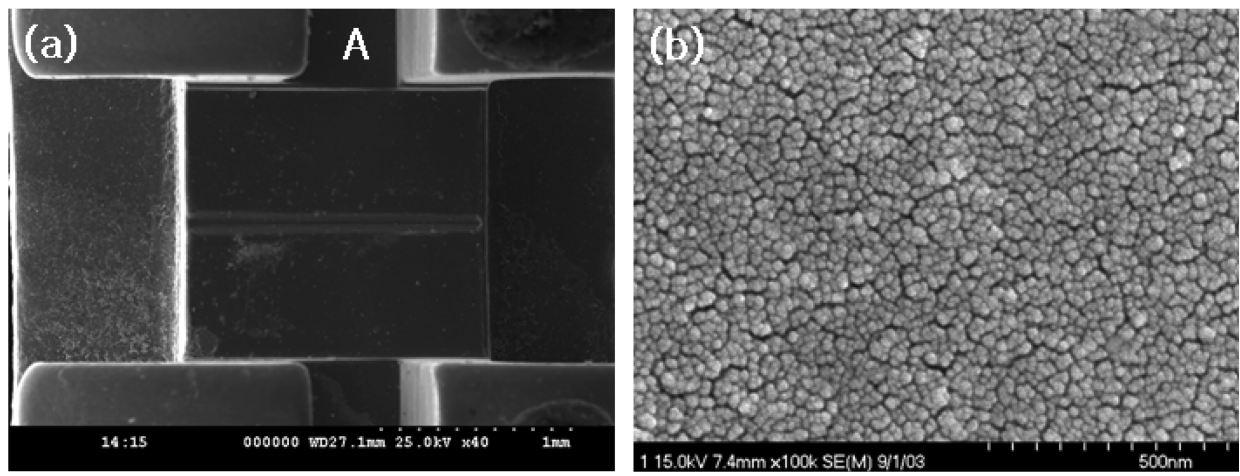

Fig. 2. The surface morphology of dental bracket observed by FE-SEM. (a) TiN-coated bracket (b) slot surface at $A$ point of photo (a).
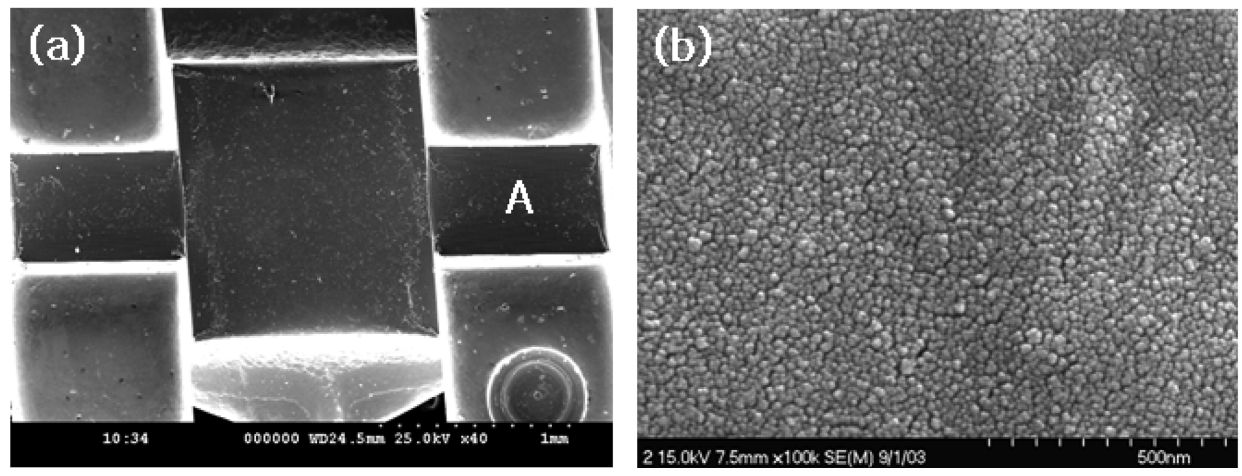

Fig. 3. The surface morphology of dental bracket observed by FE-SEM. (a) ZrN-coated bracket (b) slot surface at $A$ point of photo (a).

방향은 증착공정(기판온도, 증착속도, 모재)의 인자 에 따라 좌우되며 치밀한 성장을 하여 내식성과 내 마모성을 증가시킨다 ${ }^{7)}$ 특히 기판위에 일차로 $\mathrm{Ti}$ 를 코팅하면 더 큰 효과를 얻을 수 있는데 그 기구는 일차 코팅된 $\mathrm{Ti}$ 가 $\mathrm{TiN}$ 박막의 결정구조를 치밀한 방향으로 개선하여 코팅 층의 경도와 내마모성을 크게 향상시키고 $\mathrm{TiN}$ 으로부터 $\mathrm{N}$ 의 확산과 $\mathrm{Ti}$ 가 산 소나 탄소 같은 계면에서의 오염물질을 용해시켜 $\mathrm{TiC}$ 나 $\mathrm{TiO}_{2}$ 를 형성하여 접착성을 크게 향상시킨다 고 하였으나 코팅과정이 한 단계 증가됨에 따라 비 경제적인 관계로 기판의 온도 등 변수를 조절하여
이를 개선할 수 있다. 따라서 본 연구에서는 브라 켓과 코팅물질간에 접착성을 확보하기 위하여 ionplating법을 사용하였으며 ion-plating법은 시편과 코 팅챔버 내에서 시편에 음극을, 챔버를 양극으로 하 여 바이어스를 인가하였고 기판의 온도도 $300^{\circ} \mathrm{C}$ 이 상으로 하여 코팅하였기 때문에 우수한 코팅막의 접착성을 얻었으며 두께는 $4 \mu \mathrm{m}$ 이내로 형성하였 다. 코팅된 표면의 거칠기는 육안으로 확연히 구별 되는데 코팅된 경우가 매끄러운 형태를 보여 내마 모성을 감소시키고 전기화학적으로 안정한 표면을 제공할 수 있다는 것을 알 수 있다. 


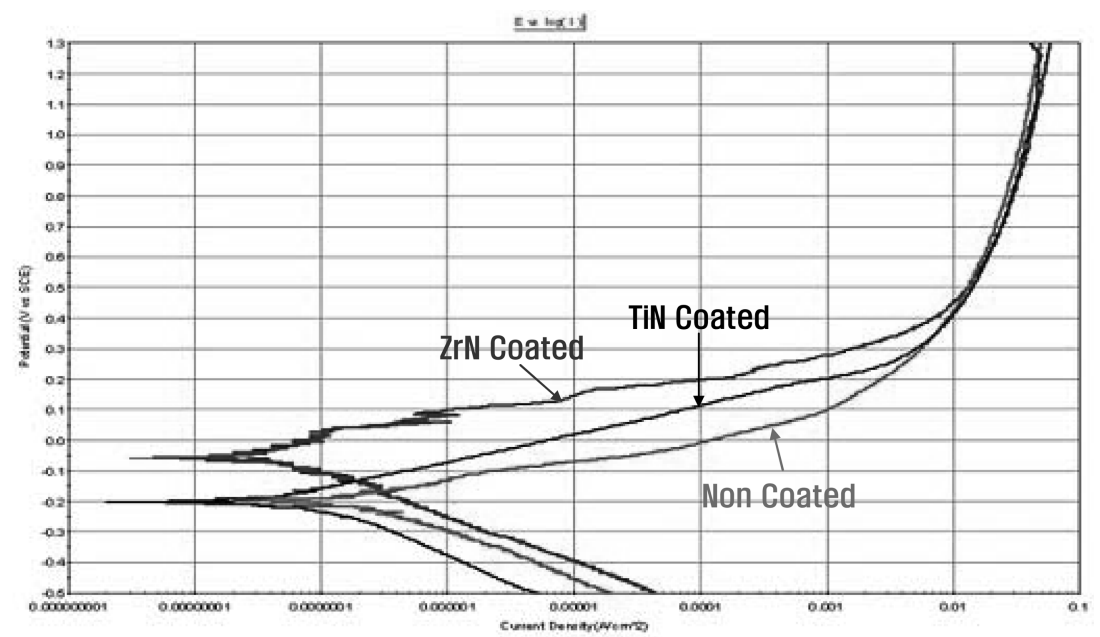

Fig. 4. Anodic polarization curves of non-coated, TiN coated and $\mathrm{ZrN}$ coated bracket after potentiodynamic test in $0.9 \% \mathrm{NaCl}$ solution at $36.5 \pm 1^{\circ} \mathrm{C}$.

\section{$3.2 \mathrm{TiN}$ 및 $\mathrm{ZrN}$ 코팅된 교정용 브라켓의 부식시험} 코팅효과가 브라켓의 부식특성에 미치는 영향을 조사하기 위하여 양극분극시험을 행한 결과를 Fig. 4 에 나타내었다. 브라켓의 마찰저항을 감소시키면서 내식성을 증가시켜야 하기 때문에 코팅처리한 효과 가 부식특성에 미치는 영향을 조사한 결과 코팅된 브라켓의 경우, 코팅되지 않은 브라켓에 비하여 전 류밀도가 전체적으로 감소하여 왼쪽에 위치하여 전 류밀도 값이 감소하는 경향을 보였다. 전류밀도는 브라켓의 표면에서 금속이온을 방출하도록 외부에 서 인위적으로 전위를 가하여 전자의 크기로 이온 의 용출을 측정하는 것이므로 전류의 크기가 작을 수록 이온의 용출이 작다는 것을 의미하므로 결국
구강 내에서 나타나는 전위가 보통 $-300 \mathrm{mV}$ 에서 $+300 \mathrm{mV}$ 범위 내에 있기 때문에 $250 \mathrm{mV}$ 를 가하여 전류밀도를 보면 $\mathrm{ZrN}$ 이 코팅된 경우가 $4.0 \times 10^{-3} \mathrm{~A} /$ $\mathrm{cm}^{2}$ 으로 가장 낮고 $\mathrm{TiN}$ 코팅의 경우, 코팅하지 않 는 경우 순으로 증가되어 $\mathrm{ZrN}$ 코팅한 경우가 전류 밀도가 가장 낮게 나타내어 내식성이 가장 우수함 을 보였다. 이는 Fig. 2와 Fig. 3에서 표면관찰을 통 하여 확인하였듯이 $\mathrm{ZrN}$ 을 코팅한 경우 아주 조밀 한 코팅이 이루어짐으로써 내식성이 크게 증가된 것으로 생각된다. 재료의 표면에서 산화와 환원이 발생되기 시작하는 부식전위 값은 $\mathrm{ZrN}$ 코팅한 경 우는 $-50 \mathrm{mV}$ 를, $\mathrm{TiN}$ 을 코팅한 경우는 $-200 \mathrm{mV}$ 를, 코팅하지 않은 경우는 $-21 \mathrm{mV}$ 로 다소 낮게 나타나
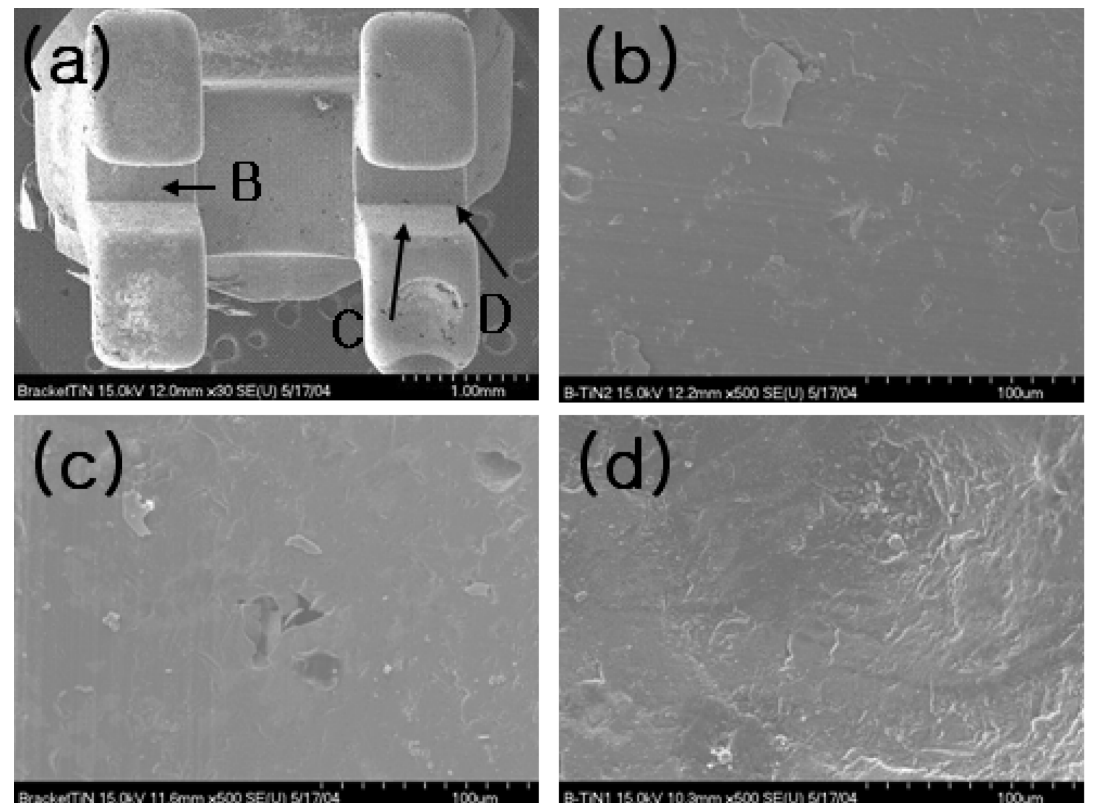

Fig. 5. FE-SEM showing corrosion morpholoty of dental bracket. (a) TiN-coated bracket. (b) slot surface at B point of photo (a), (c) slot surface at $C$ point of photo (a), (d) slot surface at D point of photo (a), after potentiodynamic test in $0.9 \% \mathrm{NaCl}$ solution at $36.5 \pm 1^{\circ} \mathrm{C}$. 
내식성이 $\mathrm{ZrN}$ 코팅한 경우가 높게 나타나 표면에 가장 안정된 피막의 형성으로 내식성이 가장 강함 을 알 수 있다.

부식시험 후 부식표면을 관찰해보면 양극분극곡 선결과와 잘 일치함을 보이는데 브라켓을 Fig. 5와 Fig. 6에서와 같이 3부분으로 나누어 FE-SEM으로 관찰해 보면 slot과 교정선이 주로 접촉하는 면과 측면의 부식표면은 거의 부식이 되지 않았고 접촉 면과 측면의 경계부위에서 부식이 발생되는 양상을 보였다. 이는 접촉면과 측면은 코팅이 잘 이루어져 평활한 면을 보이나 접촉면과 측면의 경계면에서는 코팅이 이루어졌지만 모서리부분에서 기계적인 가 공결함이 크게 나타나 코팅을 하더라도 결함이 제 거되지 않았기 때문으로 생각된다. 이러한 이유로
측면에서는 $\mathrm{pit}$ 가 관찰되고 있는데 $\mathrm{ZrN}$ 이나 $\mathrm{TiN}$ 이 코팅된 표면에서는 pit가 거의 나타나지 않는다. 이 는 $\mathrm{TiN}$ 과 $\mathrm{ZrN}$ 이 표면에 $\mathrm{TiO}, \mathrm{TiO}_{2}$ 및 $\mathrm{ZrO}_{2}$ 등과 같 은 부식생성물을 표면에 형성하는 것으로 생각된다 . 즉 $\mathrm{TiN}$ 의 경우, $\mathrm{TiN}+\mathrm{O}_{2} \rightarrow \mathrm{TiO}_{2}+1 / 2 \mathrm{~N}_{2}$ 과 같은 반응 ${ }^{8)}$ 이 촉진되고 따라서 $\mathrm{TiO}_{2}, \mathrm{TiO}_{2} \mathrm{~N}$, 및 $\mathrm{TiO}_{2} \cdot \mathrm{H}_{2} \mathrm{O}$ 가 표면에 형성됨으로써5,6, $\mathrm{Cl}^{-}$이온의 침식에 대 한 저항을 하여 공식을 억제하는 것으로 알려져 있 다. 또한 $\mathrm{pH}$ 가 5.34 인 $0.9 \% \mathrm{NaCl}$ 용액에서의 $\mathrm{TiN}$ 이 코팅되지 않은 경우 거의 부식이 되지만 $\mathrm{TiN}$ 이 코팅된 경우는 코팅층에 존재한 $\mathrm{Ti}$ 가 티타늄의 $\mathrm{pH}-$ 전위도표 ${ }^{9}$ 와 같이 $\mathrm{pH} 5.34$ 정도에서는 $\mathrm{TiO}$ 나 $\mathrm{Ti}_{2} \mathrm{O}_{3}$ 를 형성하여 내식성이 우수함을 보이며 $\mathrm{Cl}^{-}$이온 이 존재하면 $\mathrm{Ti}+2 \mathrm{NaCl}+2 \mathrm{H}_{2} \mathrm{O} \rightarrow \mathrm{TiCl}_{2}+2 \mathrm{NaOH}+$
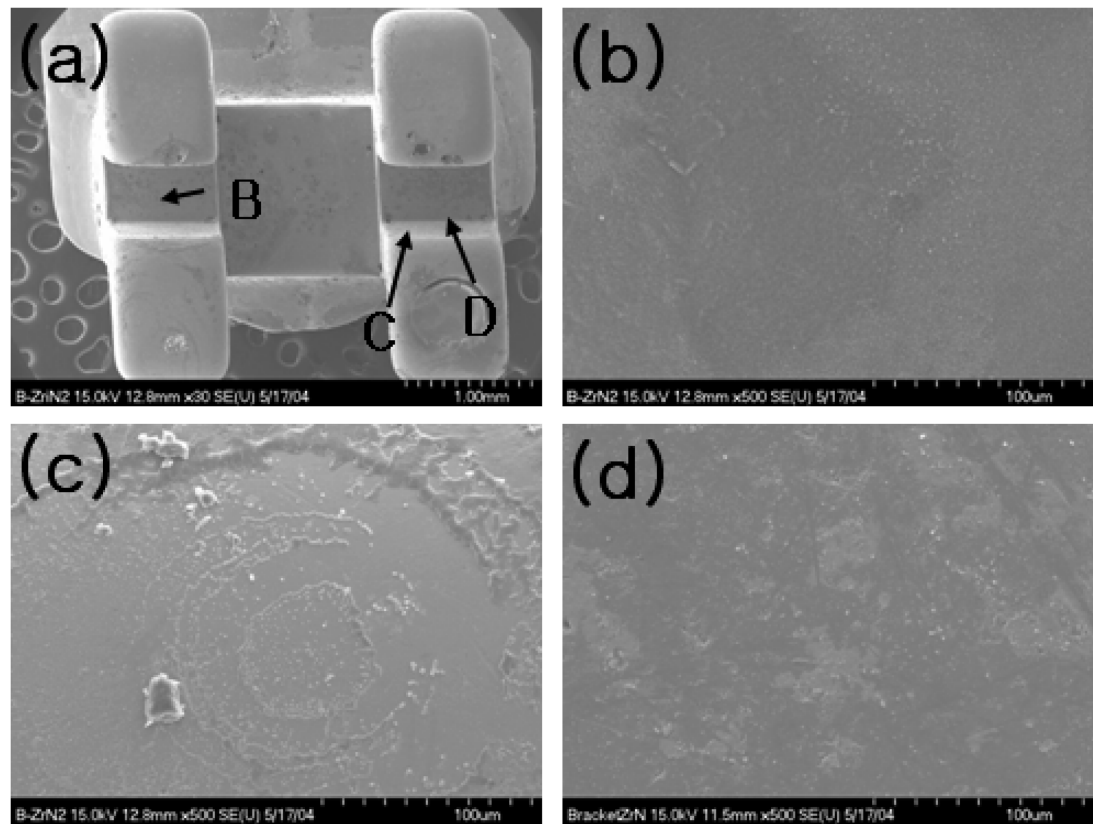

Fig. 6. FE-SEM showing corrosion morpholoty of dental bracket. (a) ZrN-coated bracket. (b) slot surface at B point of photo (a) (c) slot surface at C point of photo (a), (d) slot surface at D point of photo (a), after potentiodynamic test in $0.9 \% \mathrm{NaCl}$ solution at $36.5 \pm 1^{\circ} \mathrm{C}$.
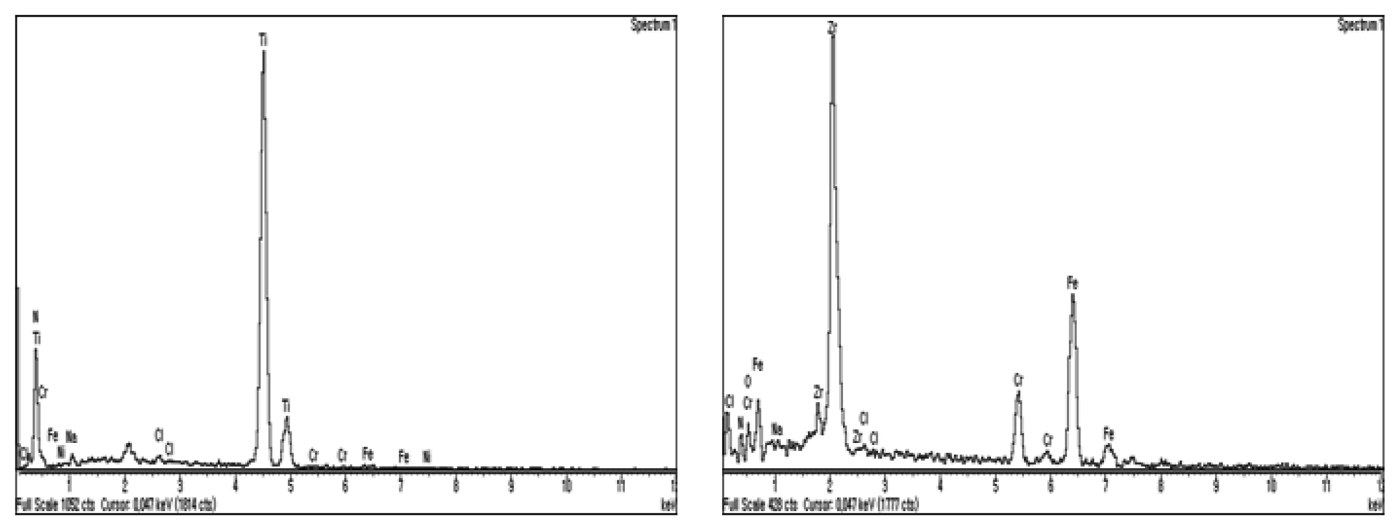

Fig. 7. EDS peaks showing the corrosion surface of $\operatorname{TiN}(a)$ and $\operatorname{ZrN}(b)$ coated bracket after potentiodynamic test in $0.9 \% \mathrm{NaCl}$ solution at $36.5 \pm 1^{\circ} \mathrm{C}$. 
$2 \mathrm{H}$ 반응으로 $\mathrm{TiCl}_{2}$ 를 표면에 형성할 수 있다. 그러 나 TiN 피막의 코팅이 완벽하게 이루어지지 않는 접촉면과 측면의 경계부위의 경우는 기계적인 결함 이 존재하여 코팅피막이 염소이온에 의해 쉽게 파 괴되면서부터 이러한 결함부위에서 $\mathrm{TiN}$ 이 귀한 (noble) 표면을 제공하고 결함부위에서 천한(base) 경향이 크게 되어 염소에 의한 자기촉매반응 ${ }^{10)}$ 을 촉진함으로써 부식이 더 심하게 발생되면서 큰 pit 가 생성될 수도 있다. 표면에 형성된 부식생성물은 표면에 주로 $\mathrm{NaCl}$ 이 석출되고 $\mathrm{Ti}$ 와 $\mathrm{Zr}$ 에 의해 형 성된 산화피막과 $\mathrm{Cr}$ 및 $\mathrm{Fe}$ 에 의한 산화물도 다소 형성되어 Fig. 7의 $\mathrm{EDS}$ 분석에서 $\mathrm{Ti}, \mathrm{N}, \mathrm{Cl}, \mathrm{Cr}$, $\mathrm{Na}, \mathrm{Zr}, \mathrm{Fe}$ 등이 검출된 것으로 생각된다.

\section{4. 결 론}

$\mathrm{TiN}$ 및 $\mathrm{ZrN}$ 코팅이 교정용 브라켓 표면특성에 미 치는 영향을 조사하기 위하여 ion-plating법을 이용 하여 $\mathrm{TiN}$ 과 $\mathrm{ZrN}$ 을 코팅한 후 표면특성을 조사한 결과 다음과 같은 결론을 얻었다.

1. $\mathrm{ZrN}$ 과 $\mathrm{TiN}$ 을 코팅한 bracket은 매끄러운 형상 을 보여 표면의 거칠기가 크게 감소되었으며 $\mathrm{ZrN}$ 코팅된 표면에서 거칠기가 가장 크게 감소되었다.

2. 브라켓에 $\mathrm{ZrN}$ 과 $\mathrm{TiN}$ 이 코팅된 경우에는 전류 밀도가 감소하고 부식전위가 증가하였으며 slot 모
서리 부분에서 공식이 발생되었다.

이러한 결과를 토대로 브라켓의 표면에 TiN 및 $\mathrm{ZrN}$ 을 코팅하여 내식성의 개선과 표면개선으로 교 정용 장치에 코팅을 행함으로써 임상적인 교정효과 를 증대시킬 수 있을 것으로 생각된다.

\section{참고문헌}

1. R. I. Damaschek, L. Strydom, H. W. Bergmann, Surf. Eng., 13 (1997) 128-132.

2. J. C. Knight, T. F. Page, Thin Solid Films, 193 (1990) 431-441.

3. E. Erturk, H. J. Heuvel, Thin Solid Films, 153 (1987) 135-147.

4. E. Harju, A. S. Korhonen, L. Jiang, E. Ristolainen, Surf. Coat. Technol., 85 (1996) 189-203.

5. A. Ramalho, M. T. Viera, A. S. Miranda, Edited by Mihaly Kosma, 3 (1993) 309.

6. H. C. Choe, Surface \& Coatings Technology, 112 (1999) 299-306.

7. H. C. Choe, Y. M. Ko, Materials Science Forum, 475 (2005) 2287-2290.

8. D. M. Brunette, P. Tengvall, M. Textor, P. Thomsen, Springer, 1 (2001) 320.

9. M. Pourbaix, Pergamon Press, 1 (1966) 193.

10. D. A. Jones, Maxwell MacMillan International Ed, New York, 1 (1992) 21. 